\title{
Influence of Nanovulin-VRKh on cattle thermoregulation and chemical composition of milk
}

\author{
M.S. Gruntkovskyi*, V.M. Kondratiuk, S.M. Gryshchenko, N.P. Hryshchenko, I.S. Mytyay \\ National University of Life and Environmental Sciences of Ukraine \\ 15 Heroiv Oborony St., 03041, Kiev, Ukraine \\ *Corresponding author E-mail: kolya gr26@ukr.net
}

Received: 16.12.2019. Accepted 15.02.2020

\begin{abstract}
The current research described the effect of neurotropic and metabolic non-hormonal biologically active medicine Nanovulin-VRKh (C) on the milk yield amount and the milk quality. Two cow groups were under study: the experimental and the control groups, each including four cows. The results showed that two of the neurotropic and metabolic Nanovulin-VRKh injections made 12 and 24 hours after the insemination did not effect the body thermoregulation of cows. Administration of the Nanovulin-VRKh contributes to stable fat formation in cow milk. Increased content of protein, nonfat milk solids, stable fat formation in milk were due to Nanovulin$V R K h$ administration. It was also established that, in the milk of experimental animals were administered the Nanovulin-VRKh, the pronounced effect of the drug on the protein, fat and nonfat milk solids content was observed, and the prolonged effect on these indices was reported during the fourth milking. Introduction of Cuprum aqua-chelate into the drug did not has toxic effect on the animal body and therefore would not effect the human health through the dairy products.
\end{abstract}

Key words: Milk yield; Milk quality; Nanovulin-VRKh; Cuprum aqua-chelate; Non-fat milk solids; Protein; Fat

\section{Introduction}

In recent years, dairy cattle breeding has become problematic. The number of calves born per 100 cows has decreased, the terms of females' economic use have reduced, while fertilization after the first insemination has decreased. Therefore, the potential task is to use biologically active drugs to regulate and stimulate the sexual function in females. One of these is biological active medicine Nanovulin-VRKh (C), which administration raises the reproductive capacity in cows (Gruntkovskyi, 2014). This drug includes Cuprum, sodium succinate, and sodium glutamate, which are dissolved in sterile distilled water.

Cuprum deficiency in the animal diet is also a problem. It plays a very important role in the processes of embryogenesis, growth, animal development, and is a necessary component for many metabolic processes and for the blood hemoglobin synthesis. The high activity of cytochrome oxidase in the embryo's tissues and the associated intensive respiration of cells and very intense movement of Cuprum from the mother's body into the fetus (Linder et al., 1999; Linder, 2002) evidence it. This trace element raises the consumption of vitamins $\mathrm{E}$ and $\mathrm{K}$ by the tissues, activates the action of insulin and inhibits the action of adrenaline, stimulates the pituitary hormones activity and the reproductive apparatus function in females and males, eliminates the toxic effect of thyroxine (Kononskyy, 2006; Mylostyva, 2011; Syvyk, 2005; Khmelnytskyy et al., 1995). In addition, Cuprum containing proteins effect carbohydrate metabolism, fat synthesis, formation of P and B vitamins (Kononskyy, 2006). However, along with the positive action, it should be noted that Cuprum is the most toxic of all trace elements in overdose. It is known that its excess in animal body causes liver damage, blocks SH-groups of proteins, especially enzymes, and raises the mitochondrial membrane permeability. Preliminary research have found that in case of Cuprum excess in the body, it is excreted with bile, urine, sweat, and with milk in females during lactation (Cooper, 2015; Kurihara, 2015).

Therefore, our study was to analyze the animal body response to the drug administration by detecting changes in body temperature and chemical composition of milk.

\section{Material and Methods}

The studies were carried out at the separate department of NULES of Ukraine "O.V. Muzychenko Velykosnitynskyi NDG" by the pairs-analogues method. Two groups were selected for this purpose, with five animals in each. The temperature measurements were performed five times: the first measurement was performed before the first injection, the second and the third measurements - 30 and 60 minutes after the first injection, the fourth and the fifth - 60 minutes before and after the second injection. The body temperature was measured rectally using a mercury thermometer. We used the neurotropic-metabolic Nanovulin-VRKh drug of nonhormonal origin and analyzed its effect on the milk yield and milk quality. The control and the experimental groups were formed of eight cows (four cows in each), which were analogous in age, live weight, lactation, productivity, and recovery period duration. The cows were kept in the same feeding and housing conditions.

In the experiment, the cows were milked twice a day, in the morning and in the evening (Table 1). The first milk sample was collected during milking prior to the drug administration. The second and the third samples - at subsequent milking 60 minutes after the first and the second injections of the drug. The fourth sample was collected at the fourth milking 12 hours after the injection. 
Table 1. Scheme of experiments with the Nanovulin-VRKh.

\begin{tabular}{|c|c|c|c|c|}
\hline Group & $\begin{array}{l}\text { Milking } 1 \\
\text { (morning) }\end{array}$ & $\begin{array}{l}\text { Milking } 2 \\
\text { (evening) }\end{array}$ & $\begin{array}{l}\text { Milking } 3 \\
\text { (morning) }\end{array}$ & $\begin{array}{l}\text { Milking } 4 \\
\text { (evening) }\end{array}$ \\
\hline ntrol, $n=4$ & $\begin{array}{l}\text { insemination (sample } \\
1 \text { ) }\end{array}$ & $\begin{array}{c}1 \text { hour before milking } \\
\text { Nanovulin-VRKh } \\
\text { 1st injection + (sample 2) }\end{array}$ & $\begin{array}{c}1 \text { hour before milking } \\
\text { Nanovulin-VRKh } \\
\text { 2nd injection + (sample 3) }\end{array}$ & (sample 4) \\
\hline $\begin{array}{l}\text { perimental, } \\
\mathrm{n}=4\end{array}$ & $\begin{array}{l}\text { insemination (sample } \\
1 \text { ) }\end{array}$ & $\begin{array}{c}1 \text { hour before milking } \\
\text { normal saline } \\
\text { 1st injection + (sample } 2)\end{array}$ & $\begin{array}{c}1 \text { hour before milking } \\
\text { normal saline } \\
\text { 2nd injection + (sample 3) }\end{array}$ & (sample 4) \\
\hline
\end{tabular}

After obtaining the milk sample, the chemical analysis was carried out using the "EKOMILK" device, to determine the weight fraction of fat, protein and nonfat milk solid. Calibration of the "EKOMILK" device was carried out every month, and the data obtained on the milk chemical composition were periodically checked and confirmed by standard acid-butyrometric methods. Determination of the Cuprum content in the selected milk samples was carried out at the laboratory of the State Research Institute of Nanobiotechnology and Resource Conservation of Ukraine by atomic emission spectrometry with inductively-coupled plasma (AES-ICP) using the Optima 210 OV device. Statistical data processing was performed using Statistica 7.0 software. Data in tables were presented like mean values $(M)$ and standard deviations $(m)$. The difference between the quantitative indices was determined using the Student's t-test, the results were considered significant at $\mathrm{p}<0.05$.

\section{Results and Discussion}

In experimental cows, the body temperature dynamics tended to decrease during the period until the second injection, although these fluctuations were within the error range. In the control group of animals, unlike the experimental group, the body temperature increase was observed. Thus, at the first measurement, it was $38.38^{\circ} \mathrm{C}$, and at the fourth one $-38.64^{\circ} \mathrm{C}(\mathrm{Table} 2)$.

Table 2. Dynamics of body temperature dynamics in experimental cows $\left({ }^{\circ} \mathrm{C}\right)$.

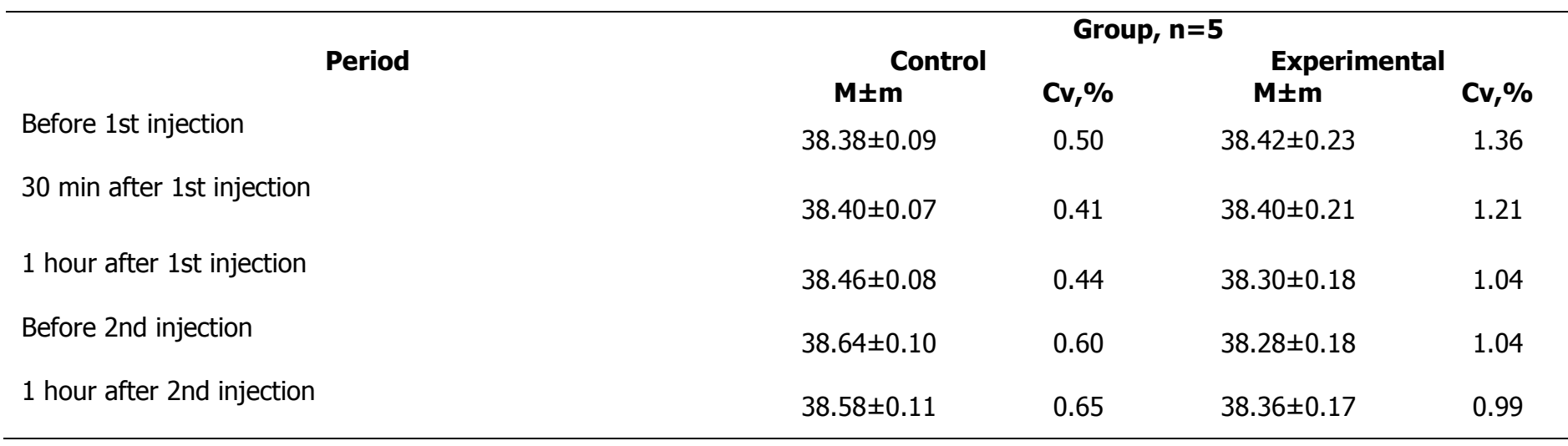

Comparing the body temperature in the animals of the experimental and control groups, we found that it was almost similar and was determined within the within the margin of error. And only at the fourth measurement in the control animals the body temperature exceeded that of experimental group by $0.36^{\circ} \mathrm{C}$.

Thus, two injections of the neurotropic-metabolic Nanovulin-VRKh made 12 and 24 hours after insemination do not affect the thermoregulation of the cow's body. In chemical analysis of milk, the following indices were taken into account: milk yield, protein, fat, nonfat milk solid, density and Cuprum content. The experimental animals were twice injected with the Nanovulin-VRKh, the time of the drug administration coincided with the second and the third milk sampling. The drug was administered 60 min before milk selection. Figure 1 shows that milk yield of the control group cows tended to grow up to the third sampling, and then decreased again, but these changes were within the margin of error. In the experimental group, on the contrary, there was a tendency to decrease the milk yield in cows. Thus, after the second injection of the drug, the milk yield was nine liters, which is reliably less than that of the control group by $13.9 \%$. After that, the milk yield value returned to the margin of error.

The next index to be studied was the fat content of milk. In milk, the fat is in the form of fat balls surrounded with a protein membrane. By its chemical composition, milk fat is a compound ester of alcohol, glycerol, and fatty acids. The proportion of fatty acids is $83-85 \%$ of fat weight part. Pure milk fat is mainly a mixture of heterogeneous triglycerols. In milk fat, the proportion of triglycerols is $98-99 \%$, diglycerols $-0.2-0.5 \%$, monoglycerols $-0.02 \%$ of the total weight (Bilonoha, 2010; Busenko, 2005).

In the cows of the control group, the increase in fat content in the second milk sample was observed in the dynamics, and in the third and the fourth samples it decreased again - by $0.4 \%$ and $0.43 \%$ compared to the second sample (Figure 2 ).

No significant fluctuations of fat content in milk were detected in the experimental group, the highest value being in the second sample as in the control group, but all these changes were determined within the margin of error.

It was found that in all four cow milk samples of the control group, the fat content was lower by $0.48 ; 0.29 ; 0.58$ and $0.71 \%$ $(p<0.05)$ compared to the experimental ones. Based on the results obtained, it can be assumed that administration of the Nanovulin-VRKh contributes to the stable formation of fat in the cow milk, as in the samples of experimental animals significant fluctuations did not occur compared to the control animals. 
We used another important index - the protein content, its proportion was about $25 \%$ of the dry matter. As chemicals, proteins are high molecular mass compounds composed of a-amino acids. One milk protein molecule may contain several hundred or even thousands of nearly twenty amino acids residues (Busenko et al., 2005).

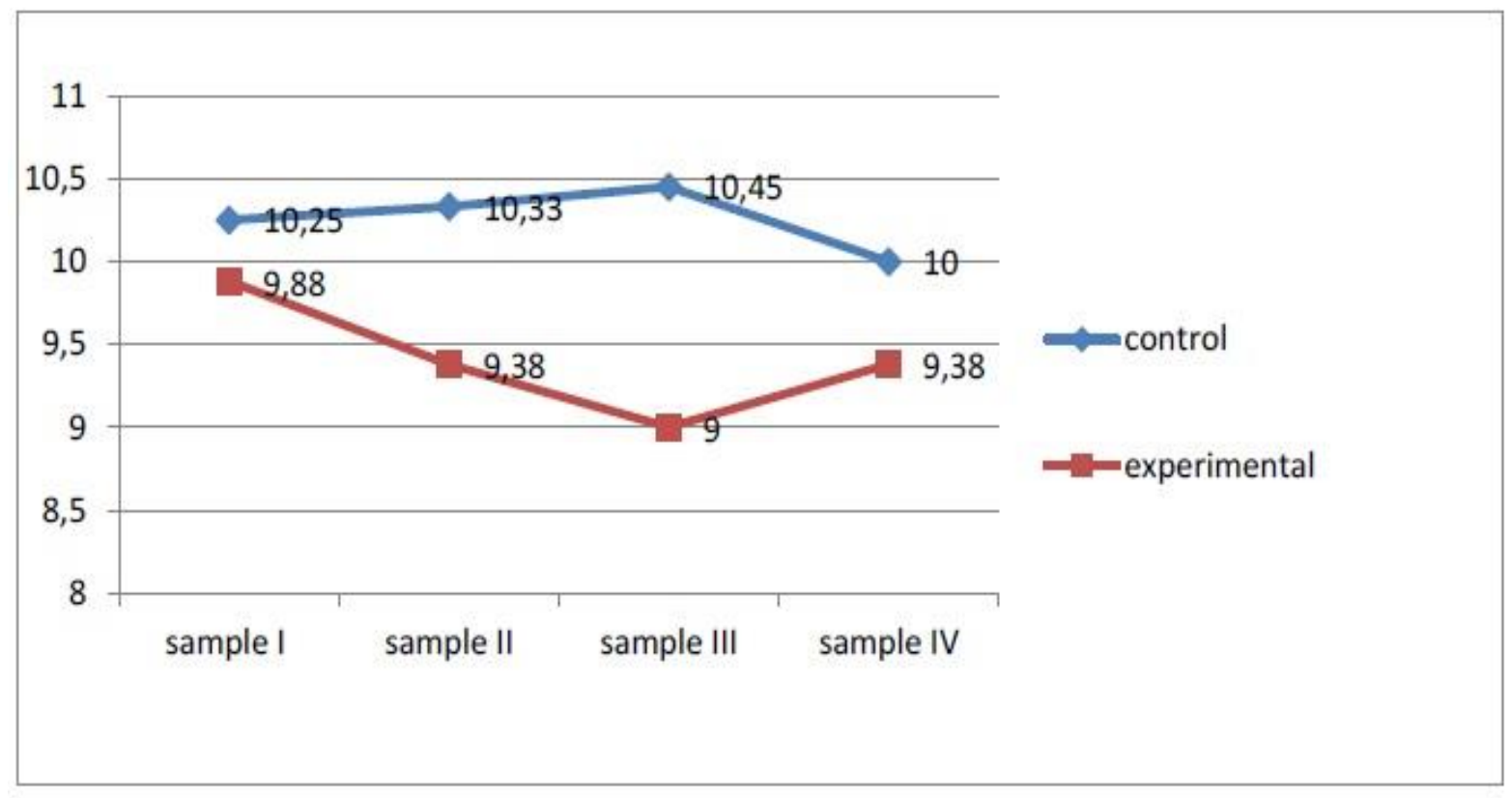

Figure 1. Milk yield, $\mathrm{kg}$.

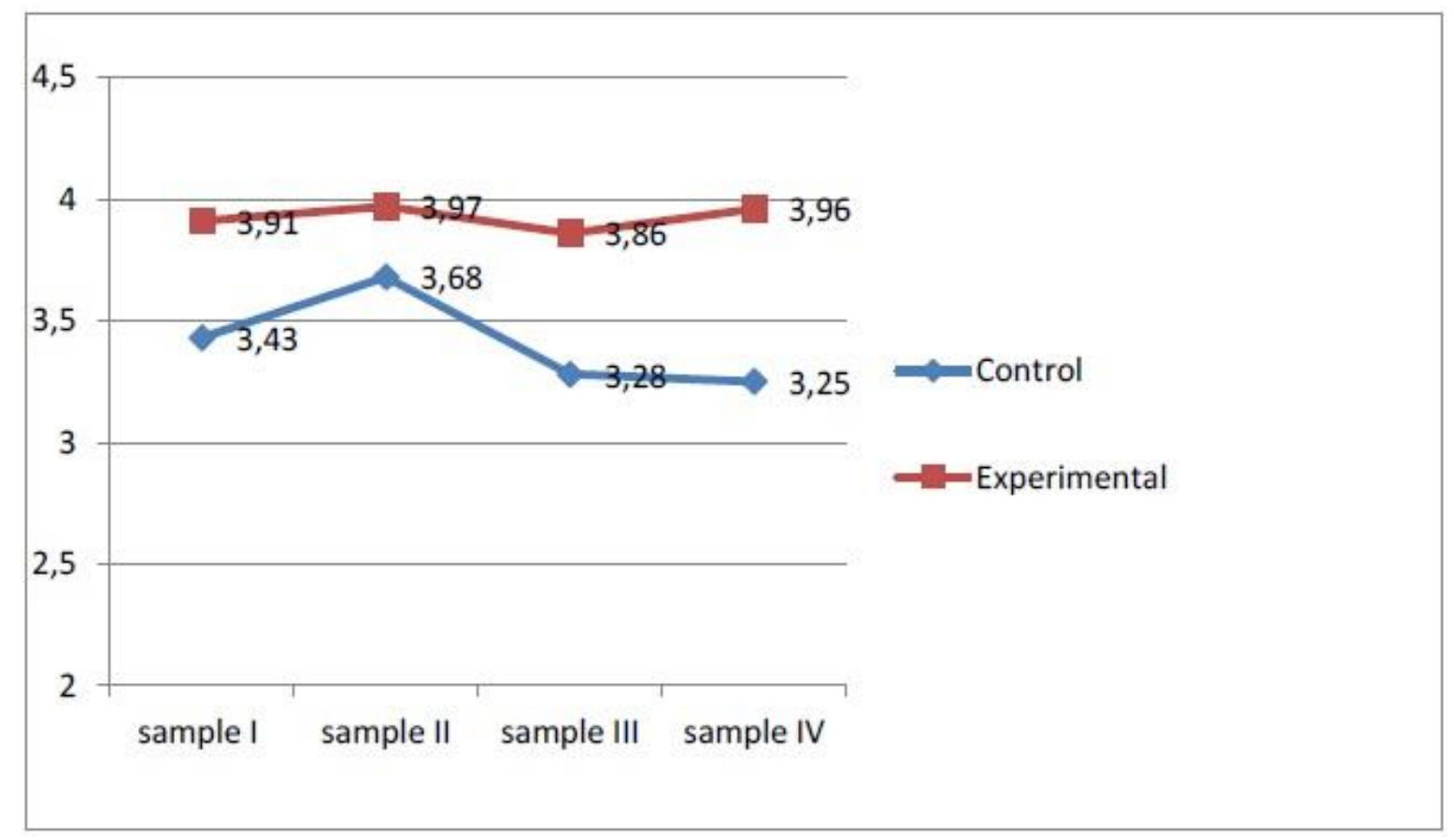

Figure 2. Milk fat content, (\%).

The main sources for the synthesis of milk proteins are casein, $\beta$-lactoglobulin and a-lactoalbumin, which are free blood amino acids that penetrate the membrane of cow lacteous gland's epithelial cells by diffusion (simple or facilitated), in which $\gamma$ glutaminetransferase system is the basis. It is characterized by broad substrate specificity, particularly to methionine, glutamine, cysteine and alanine. In the synthesis of milk proteins, the gland also absorbs glutathione from erythrocytes, which is a significant source of cysteine, glycine and glutamate. It was established that the level of protein in the control group animals' milk in the first two samples was the same and reliably decreased in the third and fourth samples (Figure 3). Experimental animals have a tendency to increase protein levels with each sample. Thus, in the first sample it was $2.90 \%$, and after two injections of the Nanovulin-VRKh the protein content increased by $0.23 \%$, and in the fourth sample it reached $3.13 \%$. Compared to the control group, the protein level in milk after the drug administration in the third and fourth samples was reliably higher than in the control by $0.17 \%$ and $0.28 \%$, respectively $(p<0.05)$. 


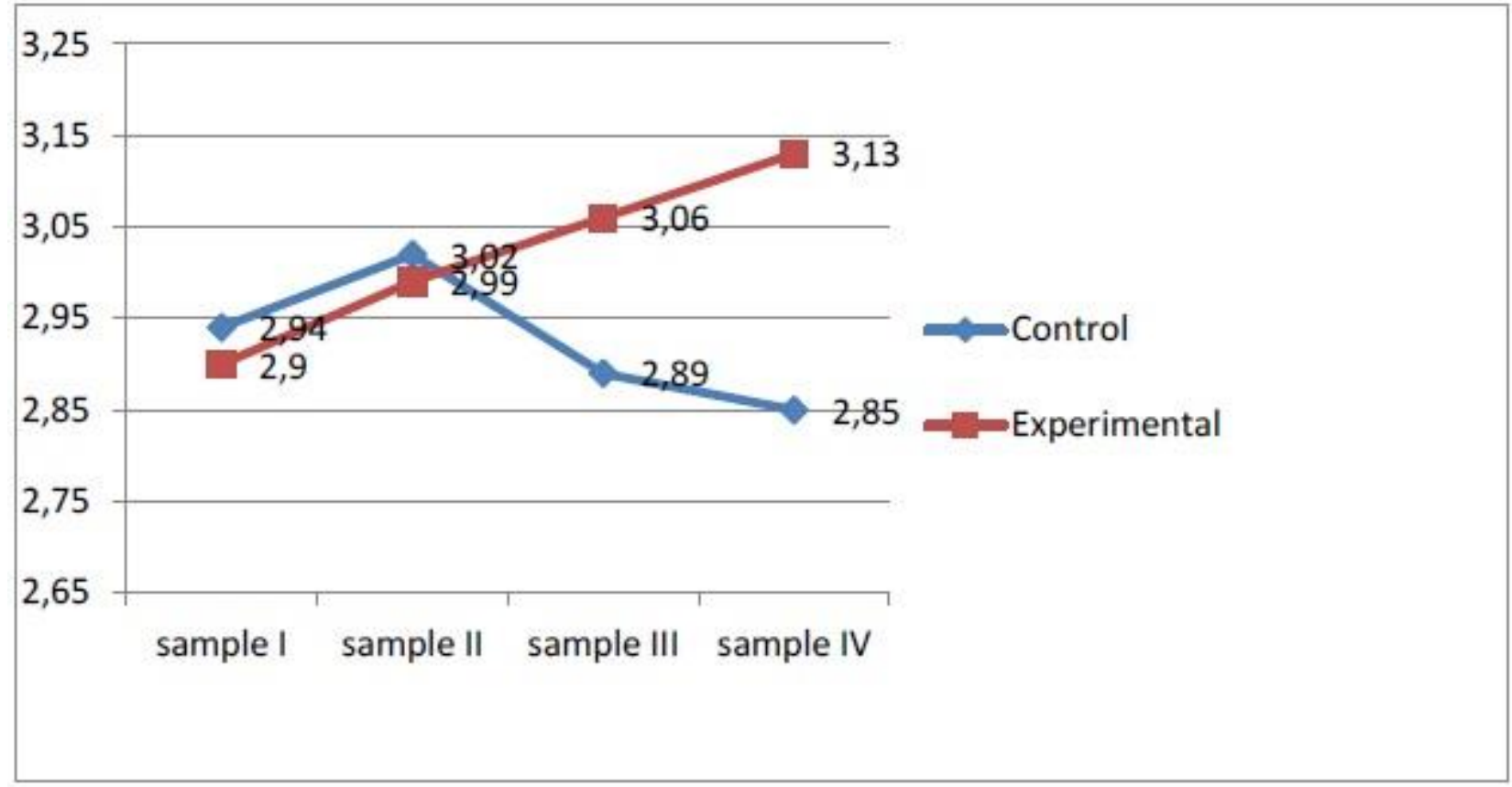

Figure 3. Milk protein content, $\%$.

Another index taken into account when assessing the milk quality was nonfat milk solids. The mass fraction of dry matter in milk is $12-13 \%$ and depends on its composition. The most variable proportion of milk solids is fat, therefore in the practice of dairy production nonfat milk solids (NFMS) indices, obtained after subtracting the fat percentage from the total milk dry matter, are frequently used (Kononskyy, 2006).

In the control group of animals, the amount of nonfat milk solids slightly changed within the range of $0.01-0.17 \%$ in the dynamics. In the experimental group, there was a tendency to an increase in the NFMS content with the drug injections, and after their completion, this index returned to the baseline. The difference between the baseline nonfat milk solids and their level in the sample after the second injection was $0.37 \%$. The highest level of nonfat milk solids in the experimental group was in the third sample, which was significantly higher than the control data by $0.35 \%$ (Figure 4 ).

Therefore, the content of nonfat milk solids in the of the control group milk did not fluctuate significantly, whereas in the experimental group it increased with the second injection of the drug up to $8.24 \%$.

Milk density is the mass of milk at $20^{\circ} \mathrm{C}$ contained per unit of volume $\left(\mathrm{kg} / \mathrm{m}^{3} \mathrm{or} \mathrm{g} / \mathrm{cm}^{3}\right)$. The density index is used to convert milk from volumetric values $(\mathrm{I})$ into $\mathrm{kg}$ and, conversely, to determine milk naturality, to calculate the amount of dry matter, nonfat milk solids (NFMS), and other components according to the formulas. The whole cow milk density ranges from 1.027 to $1.032 \mathrm{~kg} / \mathrm{m}^{3}$, in individual animals - from 1.026 to $1.034 \mathrm{~kg} / \mathrm{m}^{3}$ (Khramtsov \& Nesterenko, 2004).

In the control animals, the milk density in the first sample was $1.027 \mathrm{~kg} / \mathrm{m}^{3}$, then it decreased to $1.026 \mathrm{~kg} / \mathrm{m}^{3}$ and remained unchanged in the rest samples. The experimental group had fluctuations in the density: in the first two samples it was $1.026 \mathrm{~kg} / \mathrm{m}^{3}$, in the third - it increased to $1.027 \mathrm{~kg} / \mathrm{m}^{3}$, which coincides with the second injection of the Nanovulin-VRKh, and in the fourth sample it decreased again (Figures 3-6).

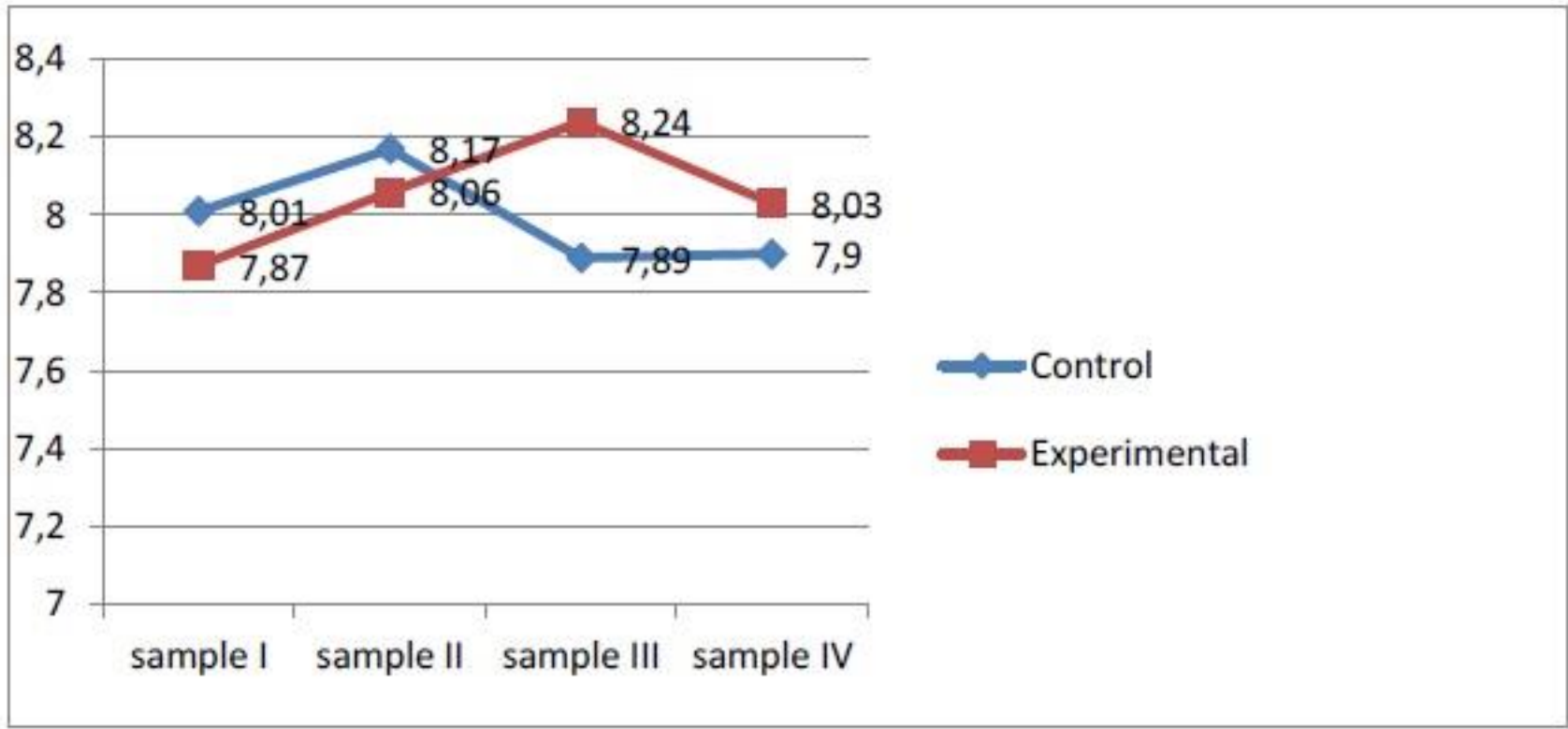

Figure 4. Content of nonfat solids in milk, (\%). 


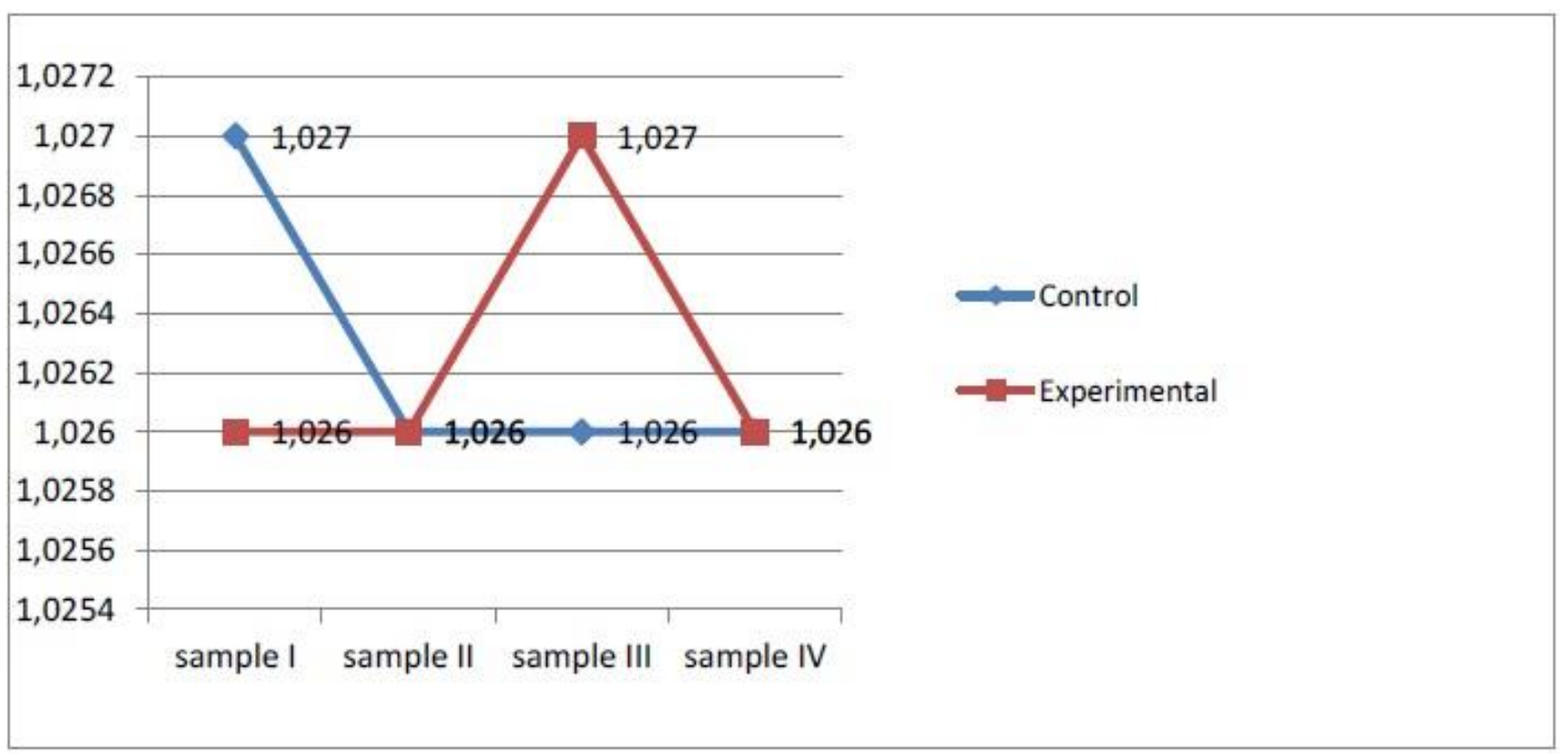

Figure 5. Milk density, $\mathrm{kg} / \mathrm{m}^{3}$.

Therefore, it can be assumed that increase in the milk protein content, nonfat milk solids and stable fat formation during the experiment compared to the control was due to administration of the Nanovulin-VRKh, rather than the milk yield decrease, since after the yield had decreased by $4.3 \%$ in the control group, it did not contribute to the increase of the above indices in the fourth sample. That is, the clear drug's effect on the content of protein, fat and nonfat milk solids is traced and its prolonged action is observed. When studying the Cuprum content in milk, it was found that the concentration of this trace element in the cow milk of the control and experimental groups fluctuates in the dynamics within $0.02-0.03 \mathrm{mg} / \mathrm{l}$. This value was at the minimum level of physiological norms, which amount to $0.02-0.72 \mathrm{mg} / \mathrm{l}$, which indicates a slight intake of this trace element by animals (Figure 6 ).

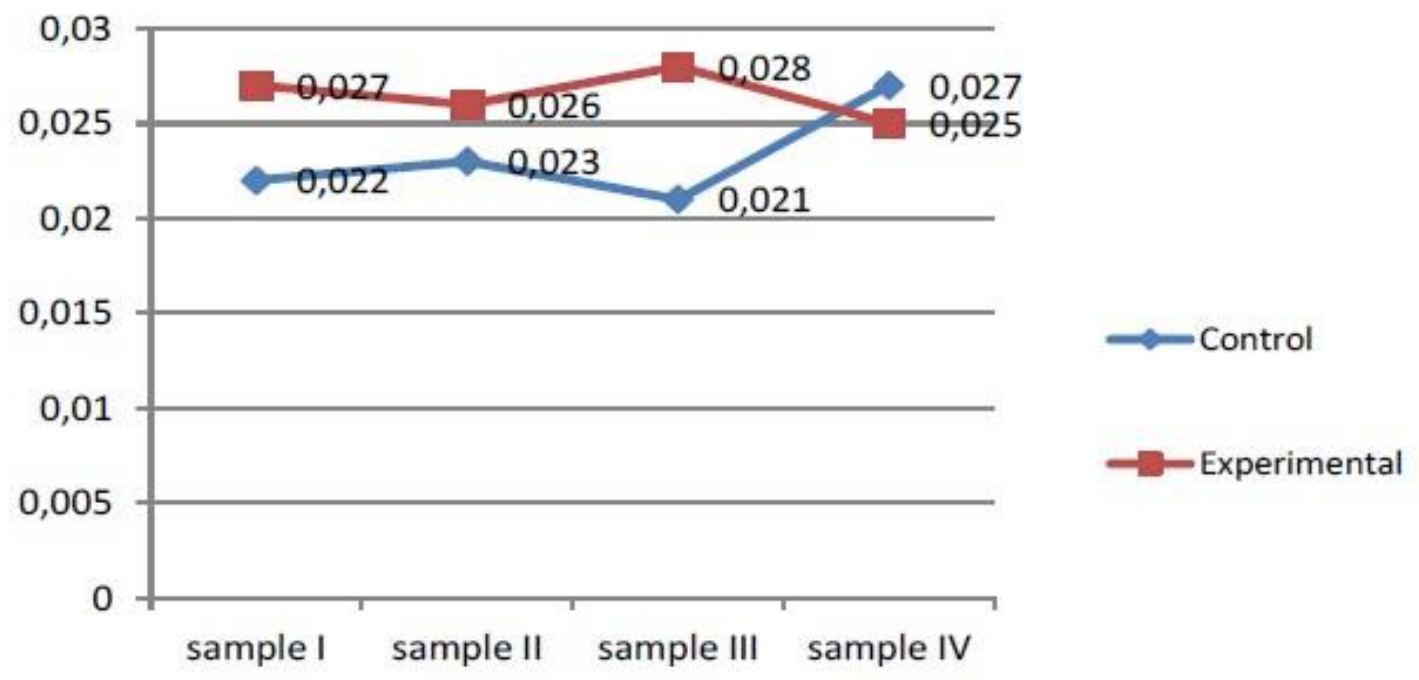

Figure 6. Cuprum concentration in milk, $\mathrm{mg} \mathrm{L}^{-1}$.

\section{Discussion}

Some researchers (Georgiyevskiy, 1990; Kononskyy, 2006; Bakircioglu, 2012) note that the absorption of certain non-essential amino acids (glutamic, aspartic, serine, proline, alanine) by the lacteous gland occurs in smaller amounts than they are excreted with milk proteins. In the animal body, among the amino acids, the first place in quantitative terms belongs to glutamic acid. Thus, according to the data characterizing the amino acid composition of casein, among the 15 presented amino acids, glutamine acid amounts to $22.4 \%$. It is involved in a large number of reactions related to energy metabolism, synthesis of amino acids, protein, carbohydrates and lipids (Braunshteyn, 2005). It is important to emphasize that only glutamic amino acid is oxidized in the cerebral tissues and is an energy source for neuronal activity. Stimulating effect on the hypothalamic-pituitary system is inherent in it, it activates the hunger and satiation regulatory centers, which in turn leads to better consumption of fodder by animals (Volkov et al.,1975). In general, our results are consistent with the data of other researchers, dealing with a similar problem (Braunshteyn, 2005; Mylostyva, 2011; Syvyk, 2005). Animals often lack important amino acids and trace elements during functional stress. The use of the drug during this period permits to increase cell activity, stimulating metabolic processes through neuroendocrine regulation, which in turn has a positive effect on the reproductive capacity and animal performance. 


\section{Conclusion}

We determined a pronounced effect of Nanovulin-VRKh (c) on the level of protein, fat and the content of nonfat milk solids in cows administered with this medicine, moreover we observed a prolonged effect on these parameters during the fourth milking. The Cuprum concentration in the cow milk from control and experimental groups were ranged from 0.02 to $0.03 \mathrm{mg} \mathrm{L}^{-1}$ and is this was a minimum physiological level. That is, the Cuprum aqua chelate administration did not has a toxic effect on the animal body and, through the products obtained, on the human body. Therefore, our research confirmed the environmental friendliness of the medicine studied, which does not cause negative changes in the animal body.

\section{References}

Bakircioglu, D., Topraksever, N., Yurtsever, S., Kizildere, M., Kurtulus, Y. B. (2016). Investigation of macro, micro and toxic element concentrations of milk and fermented milks products by using an inductively coupled plasma optical emission spectrometer, to improve food safety in Turkey. Microchemical Journal, 136, 133-138.

Bilonoha, Yu.L., Varyvoda, Yu.Yu., Turchyn I.M. (2010). Intensyfikatsiya ta optymizatsiya protsesu vyhotovlennya vershkovoho masla metodom zbyvannya. Naukovyy visnyk LNUVMBT imeni S.Z. Gzhytskoho. 2(44), 3-6. (in Ukrainian)

Braunshteyn, A.Ye. (1982). Znacheniye dlya kliniki prevrashcheniy aminokislot pod deystviyem fosfopiridoksalevykh fermentov. Vestnik AMN SSSR, 9, 3-9. (in Russian)

Busenko, O.T., Stolyuk, V.D., Mohylnyy, O.Y. (2005). Tekhnolohiya vyrobnytstva produktsiyi tvarynnytstva. Kyiv. Vyshcha osvita (in Ukrainian)

Cooper, G.A. (2015). Anatomy and Physiology of Hair, and Principles for its Collection. Hair Analysis in Clinical and Forensic Toxicology. UK: Academic Press.

Georgiyevskiy, V.I. (1990). Fiziologiya selskokhozyaystvennykh zhivotnykh. Moscow. Agropromizdat (in Russian)

Gruntkovskyi, M.S. (2014). Stymulyatsiya vidtvoryuvalnoyi zdatnosti koriv preparatom "Nanovulin VRKH". Visnyk of Sumy National Agrarian University, 2/1(24, 204-208. (in Ukrainian)

Khmelnytskyy, H.O., Khomenko, V.S., Kanyuka, O.I. (1995). Veterynarna farmakolohiya. Kharkiv: Parytet (in Ukrainian)

Khramtsov, A.G., Nesterenko, P.G. (2004). Tekhnologiya produktov iz molochnoy syvorotki: uchebnoye posobiye. Moscow. DeLi print (in Russian)

Kononskyy, O.I. (2006). Biokhimiya tvaryn: pidruch. Kyiv: Vyshcha shkola (in Ukrainian)

Kurihara, K. (2015). Nose ring for body temperature measurement of livestock e.g. cattles, has wireless unit which radio-transmits body temperature of animal measured by temperature sensor via supply of electric power from power supply unit: JP5790328-B2 Japan: A01K-015/00; A01K-067/00. JP188327; statement 31.08.11; published 07.10.15, Newsletter 201566.

Linder, M.C. (2002). Handbook of copper pharmacology and toxicology Human Press Inc. Totowa, NJ.

Linder, M.C., Donley, S., Dominquez, D. (1999). Metals and Genetics Kluwer Academic Plenum. N.Y., USA.

Mylostyva, D.F. (2011). Vplyv defitsytnoho za Kuprumom ratsionu na dynamiku utvorennya produktiv peroksydatsiyi u molodnyaku $\checkmark$ rizni periody ontohenezu. Biolohiya Tvaryn. 13(1-2), 124-130. (in Ukrainian)

Syvyk, T.L. (2005). Vplyv riznykh rivniv Kuprumu v ratsioni na produktyvnist ta vidtvornu zdatnist matok. Zb. nauk. prats Luhansk National Agrarian University. 47, 287-290. (in Ukrainian)

Volkov, M.S., Genkin, A.M., Glotov, N.A. (1975). Glutaminovaya kislota. Biokhimicheskiye osnovy prakticheskogo ispolzovaniya. Sverdlovsk: Sredne-Ural'skoye Press (in Russian).

\section{Citation:}

Gruntkovskyi, M.S., Kondratiuk, V.M., Gryshchenko, S.M., Hryshchenko, N.P., Mytyay, I.S. (2020). Influence of Nanovulin-VRKh on cattle thermoregulation and chemical composition of milk. Ukrainian Journal of Ecology, 10(1), 139-144.

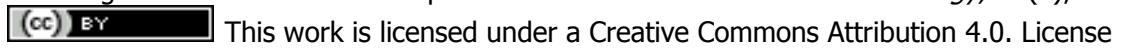

